\title{
Biogas from Slaughterhouse Waste: Towards an Energy Self-Sufficient Industry with Economical Analysis in India
}

\author{
Javed Ahmad* and Touseef A. Ansari
}

Department of Biochemical Engineering and Food Technology, Harcourt Butler Technological Institute (HBTI), Kanpur, INDIA

\begin{abstract}
Energy is the driving force for development in all countries of the world. Biochemical processes, like anaerobic digestion, can also produce clean energy in the form of biogas which can be converted to power. Using advanced and recent technologies it is now possible to develop eco-friendly processes in addition to treatment of wastewater generated by slaughter houses. The presented paper is an account of methods to control water pollution using biotechnological processes and its use to producing biogas. Use of UASB plant in large industry will fetch considerable profit to the industry in terms of energy savings. The approach promises a clean environment and better life standard.

These methods offer two important benefits of environmentally safe waste management and disposal, as well as the generation of clean electric power and fertilizer. These methods would improve the understanding of existing biological process in order to increase their efficiency, productivity, flexibility and to maintain balance of the ecosystem.
\end{abstract}

Keywords: Biochemical process; Environment; Slaughter house; Treatment; Clean electric power

\section{Introduction}

As reported by the ministry of food processing, in 2003, the country has a total of 3600 recognized slaughter houses, 9 modern abattoirs and 171 meat processing units is slaughtering over 121 million cattle's (sheep, goat, pigs and poultry) and 36.9 million buffaloes, annually, for domestic consumption as well as for export purpose [1]. On average 15 litres water wasted in each slaughtering, about 630 million gallons water wasted every year in India. Water consumption is dependent upon the type of animal slaughtered and processing operation [2].

Currently there is no organised system for disposal of both solid and liquid waste generated in slaughter houses in our country. Largely the solid waste in general is collected and dumped or disposed of in open which is unhygienic. Likewise the liquid waste too is in general added to the municipal sewage system which is not desirable as it may contain objectionable components that may affect working of municipal sewage treatment plants. Waste discharges into water bodies must comply with prescribed standard laid by state and central pollution control agencies [Environment (protection) Act, 1986] [3]. Worldwide legislations on regulating the disposal of slaughter house wastewater and solid waste are not yet uniform [4]. The major deleterious effect of these wastes on natural water bodies is there deoxygenation. The recommended methods for treatment and disposal of slaughter house waste include [5].

1) Screening

2) Incineration

3) Land filling

4) Skimming

5) Primary settling

6) Blood separation

7) Protein recovery
8) Biological treatment such as composting and biomethanation.

The waste from slaughter houses have similar chemical characteristics as those of domestic sewage but are considerably more concentrated in general they are almost wholly organic. Subjects of slaughtering of animals and related activities are governed as state subject under the provision of article 48 of the constitution of India [3].

The waste from slaughter should not mix with the municipal drain system without pre-treatment and management meeting sewage standard as per the Bureau of Indian Standard (BIS) [3]. Effluent from slaughterhouse is moderate to high strength complex wastewater containing about $45 \%$ soluble and $55 \%$ coarse suspended organics. The composition and flow generally depend on the number of animal killed [6]. The utilization of suspended organics can be done by digestion in the production of biogas. Anaerobic digestion is the best option with production of biogas, reduced green house gases and pollution control [7] (by slaughter house waste [8-12]). The success of process, especially the effective removal of BOD (Biochemical oxygen demand) has potential for use of biogas plant for treatment of slaughterhouse effluent. The slaughterhouse operation generates a strong effluent of variable character, depending on the degree of blood recovery [13].

Typical characteristics of composite effluent from the slaughter house are as follows:

\section{Parameters characteristic}

1. Quantity - 1800 cum/day

*Corresponding author: Javed Ahmad, Department of Biochemical Engineering and Food Technology, Harcourt Butler Technological Institute (HBTI), Kanpur, INDIA, Tel: 09807121672; E-mail: Javedkkhaan@gmail.com

Received June 30, 2012; Accepted August 20, 2012; Published August 24, 2012

Citation: Ahmad J, Ansari TA (2012) Biogas from Slaughterhouse Waste: Towards an Energy Self-Sufficient Industry with Economical Analysis in India. J Microb Biochem Technol S12:001. doi:10.4172/1948-5948.S12-001

Copyright: ( 2012 Ahmad J, et al. This is an open-access article distributed under the terms of the Creative Commons Attribution License, which permits unrestricted use, distribution, and reproduction in any medium, provided the original author and source are credited 
2. Total solids - $3700-4600 \mathrm{mg} / \mathrm{l}$

3. BOD - $4100 \mathrm{mg} / \mathrm{l}$

4. COD - $7700 \mathrm{mg} / \mathrm{l}$

5. $\mathrm{pH}-6-7$

6. Moisture - 70\%-75\%

\section{Materials and Methods}

\section{Materials}

Samples: Slaughter house liquid waste was collected from Slaughter Houses located in Kanpur Nagar, India.

UASB reactor: A glass vessel of capacity 20 litres with internal constructional feature as shown in Figure 1 was used as UASB reactor in this study. The reactor had provision for multipoint feed entry, gas outlet and outlet for treated effluent.

Seed: The seed for UASB reactor was obtained from anaerobic digester which is being used for treatment of composite tannery effluent in Jajmau, Kanpur (INDIA).

\section{Methods}

The aim of study was to investigate use of UASB process for treatment of slaughter house wastewater. Study was performed on effect of loading rates, temperature, time and recycle ratio on methane production. The reactor was run continuously. COD (Chemical Oxygen Demand) reduction and methane production rates were used as criteria for assessment of reactor performance.

The study revealed that the reactor gave satisfactory performance for high loading rates without any reduction in quantity and quality of biogas. Also the reactor did not show much sensitivity to temperature variation even when the reactor was operated at low temperatures. Higher temperatures gave higher gas production rates on account of increased digestion rates. Effect of recycling of treated effluent was also investigated. A recycle ratio of 1.5 enhanced biogas formation due to utilization of residual BOD (Biochemical Oxygen Demand). Further studies are in progress to treat slaughterhouse wastewater with higher loading rates besides running the reactor satisfactorily at low temperature range $15-25^{\circ} \mathrm{C}$ to reduce heating requirements especially in winter season. The results of these studies are shown in Table 1-4 and depicted in Figure 2-5.

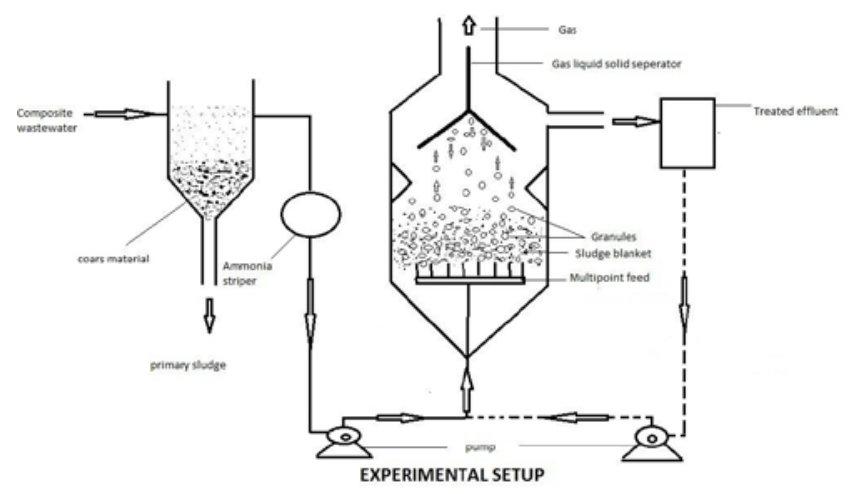

Figure 1: Experimental Setup of UASB Reactor.

\section{Result and Discussion}

As can be seen from Table 1 the reactor did perform satisfactorily for a wide range of loading rates $\left(1.5-4.0 \mathrm{~kg} \mathrm{COD} / \mathrm{m}^{3}\right.$-day) corresponding to methane yield $\left(\mathrm{m}^{3} / \mathrm{kg}\right)$ between $0.254-0.321$.Maximum methane
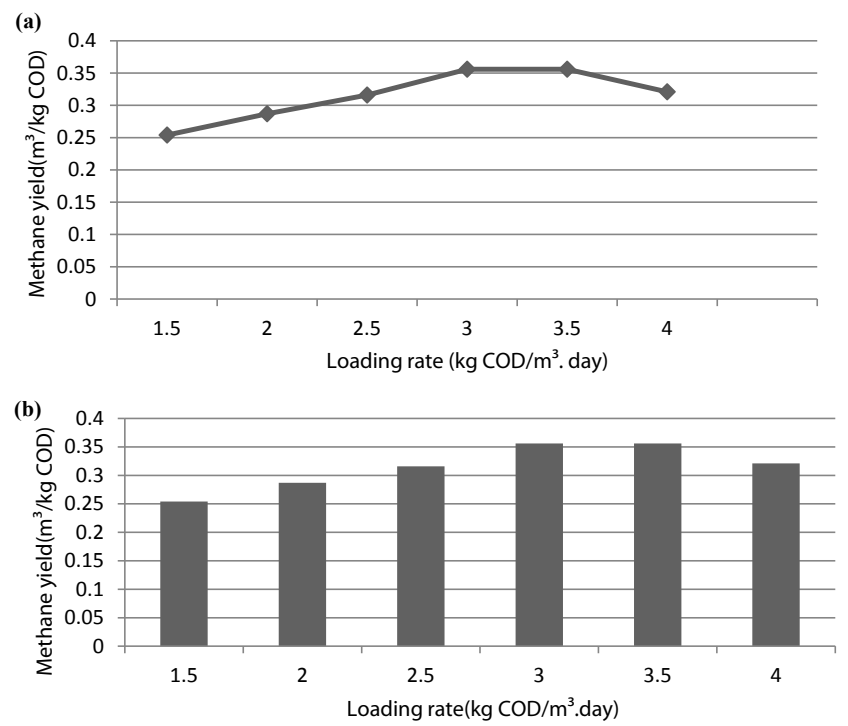

Figure 2: Effect of Loading Rates on Methane Production..

\begin{tabular}{|c|c|c|}
\hline S.No. & $\begin{array}{l}\text { LOADING RATE } \\
\text { (kg COD } / \mathrm{m}^{3} \text { day) }\end{array}$ & $\begin{array}{l}\text { METHANE YIELD } \\
\left(\mathrm{m}^{3} / \mathrm{kg} \text { COD }\right)\end{array}$ \\
\hline 1 & 1.5 & 0.254 \\
\hline 2 & 2.0 & 0.287 \\
\hline 3 & 2.5 & 0.316 \\
\hline 4 & 3.0 & 0.356 \\
\hline 5 & 3.5 & 0.356 \\
\hline 6 & 4.0 & 0.321 \\
\hline
\end{tabular}

(Temperature: $40^{\circ} \mathrm{C}$ HRT: 24 hours)

Table 1: Effect of Loading Rates on Methane Production.
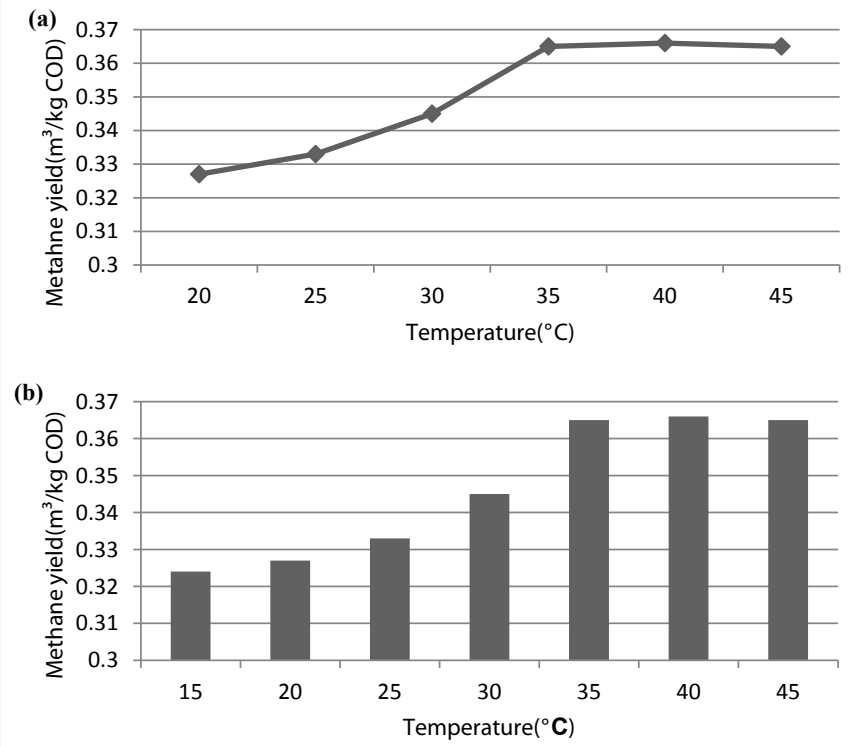

Figure 3: Effect of Temperature on Methane Production. 
yield was observed at loading rates 3 and 3.5 and minimum 0.254 at 1.5. For loading rate 4.0 gas production decreased a little $(0.321)$. These results are also presented in diagrams (Figure 2). Methane production was not much affected when the reactor was operated at low $\left(15-20^{\circ} \mathrm{C}\right)$ temperatures giving methane yield between 0.324-0.333. However, as can be seen from Table 2, gas production showed an increasing trend when the temperature was raised up to $45^{\circ} \mathrm{C}$ giving maximum yield of 0.366 at $40^{\circ} \mathrm{C}$. Effect of temperature is shown in diagrams (Figure 3 ). While studying the effect of incubation period with recycling the treated effluent only (without fresh feed supplied to the reactor) for more than 1 day it was found that methane production continuously increased from 0.323 (on first day) to 0.410 on day 10.This increasing trend in methane production may certainly be due to continuous utilization of residual COD in recycled stream. Figure 4 depicts this

\begin{tabular}{|c|c|c|}
\hline S.No. & TEMPERATURE $\left({ }^{\circ} \mathrm{C}\right)$ & $\begin{array}{c}\text { METHANE YIELD } \\
\left(\mathrm{m}^{3} / \mathrm{kg} \text { COD }\right)\end{array}$ \\
\hline 1 & 15 & 0.324 \\
\hline 2 & 20 & 0.327 \\
\hline 3 & 25 & 0.333 \\
\hline 4 & 30 & 0.345 \\
\hline 5 & 35 & 0.365 \\
\hline 6 & 40 & 0.366 \\
\hline 7 & 45 & 0.365 \\
\hline
\end{tabular}

(Loading rate: $3 \mathrm{~kg} \mathrm{COD} / \mathrm{m}^{3}$.day HRT: 24 hours)

Table 2: Effect of Temperature on Methane Production.
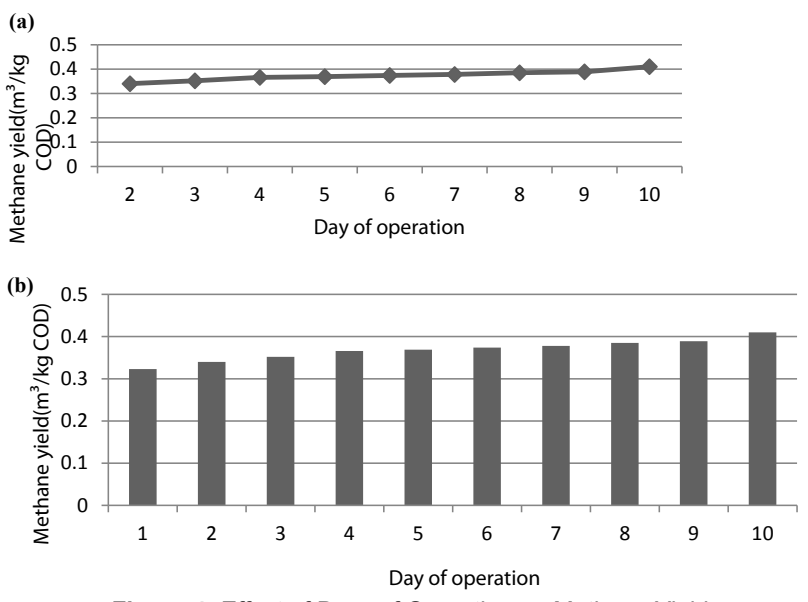

Figure 4: Effect of Days of Operation on Methane Yield.

\begin{tabular}{|c|c|c|}
\hline S. No. & DAY OF STUDY & $\begin{array}{c}\text { METHANE YIELD } \\
\left(\mathbf{m}^{\mathbf{3}} / \mathbf{k g} \text { COD) }\right.\end{array}$ \\
\hline 1 & 1 & 0.323 \\
\hline 2 & 2 & 0.340 \\
\hline 3 & 3 & 0.352 \\
\hline 4 & 4 & 0.366 \\
\hline 5 & 5 & 0.369 \\
\hline 6 & 6 & 0.374 \\
\hline 7 & 7 & 0.378 \\
\hline 8 & 8 & 0.385 \\
\hline 9 & 9 & 0.389 \\
\hline 10 & 10 & 0.410 \\
\hline
\end{tabular}

(Temperature $40^{\circ} \mathrm{C}$ Loading rates: $3 \mathrm{~kg} \mathrm{COD} / \mathrm{m}^{3}$ day HRT: 24 hours)

Table 3: Effect of Days on Methane Production (With Total Recycling).
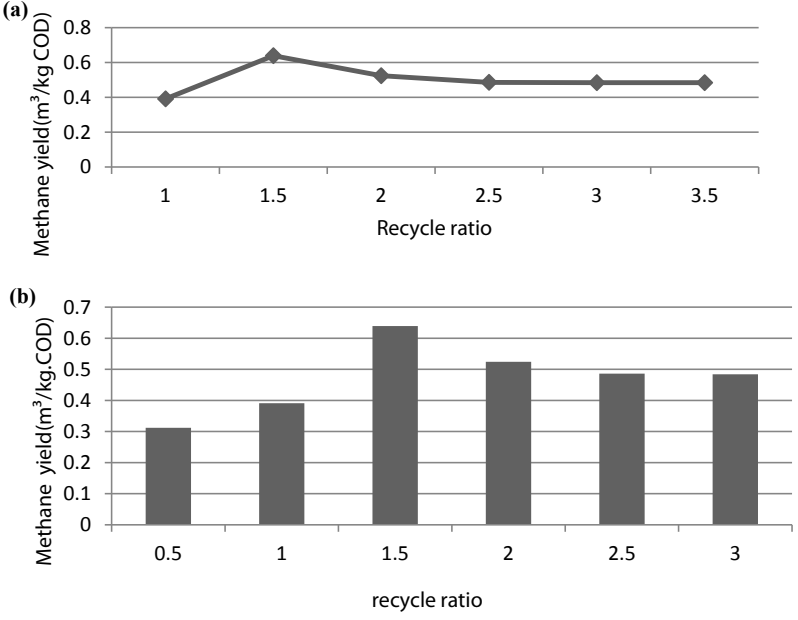

Figure 5: Effect of Recyle Ratio on Methane Production.

\begin{tabular}{|c|c|c|}
\hline S. No. & Recyle ratio & Metahne yield( $\mathbf{m}^{\mathbf{3}} \mathbf{k g}$ COD) \\
\hline 1 & 0.5 & 0.312 \\
\hline 2 & 1.0 & 0.391 \\
\hline 3 & 1.5 & 0.639 \\
\hline 4 & 2.0 & 0.524 \\
\hline 5 & 2.5 & 0.486 \\
\hline 6 & 3.0 & 0.484 \\
\hline 7 & 3.5 & 0.484 \\
\hline
\end{tabular}

(Temperature $40^{\circ} \mathrm{C}$ Loading rate: $3 \mathrm{~kg} \mathrm{COD} / \mathrm{m}^{3}$ day HRT: 24 hours)

Table 4: Effect of Recycle Ratio on Methane Production.

observation. Further, using a recycle ratio (1.5) with supply of fresh feed to the reactor gave better yield (0.639) of methane than without recycling suggesting that use of a recycled system is more beneficial in term of reactor space and process efficiency than that of a system without recycle.

\section{Conclusion}

The results of this study show that UASB process can be effectively used for treatment of slaughter house wastewater. The system can efficiently remove suspended as well as soluble organics from wastewater. Also the reactor has its applicability for use at low temperatures with satisfactory biogas production.

Economical aspects of biomethanation of slaughter house waste

\section{Utilization of primary sludge:}

- Fertilizer: After composting of primary sludge, it can be used as fertilizer. Studies have shown that composts are valuable fertilizer having much higher content of N, P, Ca, Zn and $\mathrm{Cu}$ compared to farmyard manure. These materials could be used in crops having a larger fertilizer demand like sugar beet and also fibre crops or cereals. Residual effects of composts are pronounced. In normal years the yield increased 3 fold compared to control. Differences are significant in case of stronger composts even in 2006 in the $4^{\text {th }}$ and $5^{\text {th }}$ experimental years [14].

- Animal feed: As India ranks top most in world in live stock holding and has the potential to utilize primary sludge to partially meet the growing requirement of animal feed, the total 
Citation: Ahmad J, Ansari TA (2012) Biogas from Slaughterhouse Waste: Towards an Energy Self-Sufficient Industry with Economical Analysis in India. J Microb Biochem Technol S12:001. doi:10.4172/1948-5948.S12-001

Page 4 of 4

requirement of animal feed has been estimated at 37 million tonnes. This includes 24 million tonnes of cattle feed (which as per the directive of the Department of Animal Husbandry, Government of India cannot have slaughter house waste material). Slaughterhouse waste material has the potential to partly replace 13 million tonnes of animal feed material. Slaughterhouse wastes can be used as inputs to feeds for the poultry, fish and pets like dogs and cats $[15,16]$.

\section{Utilization of biogas:}

- In electricity generation: There are different kinds of technology to convert the chemical energy in the biogas into electricity. In biogas conversion, the chemical energy in the molecules is converted to mechanical energy in a controlled combustion system, then, this mechanical energy activates a generator producing electrical power. The gas turbines and the internal combustion engines are the most common technologies used to this kind of energy conversion. Even so, in general, engines are more efficient turbines and may be more efficient when operating in a cogeneration cycle producing heat and electricity.

The amount of biogas produced from UASB ranges from $0.254 \mathrm{~m}^{3} /$ $\mathrm{kg}$ COD to $0.639 \mathrm{~m}^{3} / \mathrm{kg}$ COD in 24 hours. So the electricity ranges from $0.508 \mathrm{kWhr}$ to $1.278 \mathrm{kWhr}$ for a small 20 litre lab made UASB. On average 3000 litres of wastewater generated per day from a large scale slaughter house (if 200 animals slaughtered per day). Thus use of UASB plant in large industry will fetch considerable profit to the industry in terms of energy savings. For example, treating of 3000 litres of waste water will give an average $147.67 \mathrm{~m}^{3}$ of biogas/day, which could be utilized to produce $294 \mathrm{kWhr} / \mathrm{m}^{3}$-day of electricity.

Investment cost of whole setup is moderate and the potential of self-help for construction is relatively high. However, planning and design requires skilled labour and experienced experts. Both biogas and fertilising sludge obtained through this technology is highly interesting from an economic point of view. Operational requirements are very low and no professional operator is required as long as the plant is well maintained by skilled users. Accumulated slurry in the bottom of the reactor needs to be de-sludge every two to five years, depending on the type of reactor. The reactors should also regularly be checked for foaming, scum formation or gas tightness. In Table 5 , it is obvious that the cost of biogas machinery will come out around in 3 years.

\begin{tabular}{|r|r|c|}
\hline \multicolumn{2}{|c|}{ Particulars } & Value \\
\hline a & Waste processing & 3000 litre/day \\
\hline b & Capital cost & 12 lakh \\
\hline c & Operation \& maintenance cost & 1.2 lakh/year \\
\hline \multicolumn{3}{|r|}{ Potential returns } \\
\hline d & Biogas generation \\
\hline e & Equivalent power @ 2 kwh/m & $294 \mathrm{kWhr} /$ day \\
\hline f & Cost of power @ Rs. 4/kwh & 4.3 lakh/year \\
\hline g & Quantity of manure & $75 \mathrm{~kg} /$ day \\
\hline h & Cost of manure @ Rs. 3/kg & 0.8 lakh/year \\
\hline \multicolumn{2}{|c|}{ Savings after O\&M [(h+f)-c] } & 3.9 lakh/year \\
\hline
\end{tabular}

Table 5: Economics of a Biogas Plant.
Economical analysis of a biogas plant which is utilizing of an industrial level slaughter house wastewater is shown in Table 5.

\section{Acknowledgement}

Authors thank Associate Professor S.J. Nagar (H.B.T.I. KANPUR) for his support and encouragement.

\section{References}

1. Ministry of food processing industries.

2. Wu PF, Mittal GS (2011) Characterization of provincially inspected slaughterhouse wastewater in Ontario, Canada. Canadian Biosystems Engineering 53: 6.9-6.18.

3. Ministry of Urban Development. Government of India

4. Mittal GS (2007) Regulations related to land-application of abattoir washwater and residues. International Commission of Agricultural Engineering 9.

5. Centre for environment and development (2012) Peoples sustainability Treaties. CED Hosts International Secretariat of Peoples' Sustainability Treaties for Rio+20.

6. Manjunath NT, Mehrotra I, Mathur RP (2000) Treatment of wastewater from slaughter house by DAF-UASB system Water Res 34: 1930-1936.

7. Ravindranath E, Kalyanaraman C, Shamshath BS, Gopalakrishnan NA (2010) Effect of Recirculation Rate on Anaerobic Treatment of Fleshing Using UASB Reactor with Recovery of Energy. J Sci Ind Res (India) 69: 790-793.

8. Baldasano JM, Soriano C (2000) Emission of greenhouse gases from anaerobic digestion processes: comparison with other municipal solid waste treatments Water Sci Technol 41: 275-282.

9. Borjaa R, Banks CJ, Wang Z (1994) Performance and kinetics of an upflow anaerobic sludge blanket (UASB) reactor treating slaughterhouse wastewater. J Environ Sci Health A Tox Hazard Subst Environ Eng 29: 2063-2085

10. Salminen E, Rintala J (2002) Anaerobic digestion of organic solid poultry slaughterhouse waste--a review. Bioresour Technol 83: 13-26.

11. Salminen EA, Rintala JA (2002) Semi-continuous anaerobic digestion of solid poultry slaughterhouse waste: effect of hydraulic retention time and loading Water Res 36: 3175-3182.

12. Sayed S, de Zeeuw W (1988) The performance of a continuously operated flocculent sludge UASB reactor with slaughterhouse wastewater. Biological Wastes 24: 199-212.

13. del Pozo R, Okutman Tas D, Dulkadiroglu H, Orhon D, Diez V (2003) Biodegradability of slaughterhouse wastewater with high blood content unde anaerobic and aerobic conditions. J Chem Technol Biotechnol 78: 384-391.

14. IEA Bioenergy (2012) Task 37: Energy from Biogas and Landfill Gas. Moss, Norway.

15. Department of Animal Husbandry, Dairying \& Fisheries. Ministry of Agriculture Government of India.

16. Technology Information, Forecasting and Assessment Council (TIFAC).

This article was originally published in a special issue, Bioresource Technology handled by Editor(s). Dr. Gu Tingyue, Ohio University, USA 